\title{
Studies to Improve Wheat for High Temperature Stress Areas
}

\author{
Suman Bakshi", Vikash Kumar, Abhijit Shitre, Bikram Kishore Das \\ Nuclear Agriculture \& Biotechnology Division, Bhabha Atomic Research Centre, Trombay, Mumbai, India
}

Email address:

sood004@gmail.com (S. Bakshi), sumansud@barc.gov.in (S. Bakshi)

\section{To cite this article:}

Suman Bakshi, Vikash Kumar, Abhijit Shitre, Bikram Kishore Das. Studies to Improve Wheat for High Temperature Stress Areas. American Journal of BioScience. Vol. 3, No. 3, 2015, pp. 64-69. doi: 10.11648/j.ajbio.20150303.11

\begin{abstract}
Heat stress is one of major limitations in wheat (Triticum aestivum L.) productivity in arid, semiarid, tropical and semi tropical regions of world. Wheat is grown as winter cereal crop in subtropical countries like India. The crop experiences chronic high temperature at most of phenological stages of growth. A detailed understanding of genetic variation and mechanisms of heat tolerance in wheat would facilitate development of intrinsically thermotolerant genotypes. To understand thermotolerance of currently grown wheat varieties, studies on physiological assays at seedling stage, canopy temperature depression (CTD), dry matter translocation (DMT) were carried out along with estimation of field performance. Seedling screening assays identified varieties showing thermotolerance at seedling stage and showed association with high temperature tolerance at adult plant stage. Advanced generation selections were developed from the crosses involving these genotypes, which showed yield advantage over standard check in rod row trials at three different locations. The thousand-kernel weight for these selections ranged from 47.7 to $50.1 \mathrm{~g}$ with average increase of $13 \%$ over the parental mean at Pune location. Studies on an alternative dwarfing gene $R h t 8$, known to reduce plant height by 10 percent without significant reduction in yield under high temperature was also undertaken. Genotypic and phenotypic analysis of 92 genotypes confirmed the absence of $R h t 8$ gene in the cultivated varieties of India. Rht8 gene was transferred to tall genotypes viz. Ajantha and MP3054 from donor Chuan Mai18. Studies on canopy temperature depression on a set of varieties in complementation with dry matter translocation established that cooler canopies with a longer grain-filling period of 40-42 days after ear emergence showed advantage under continual heat stress throughout growth period. Further research is in continuation to dissect and understand the genetic basis to variation in heat stress tolerance exhibited by different varieties.
\end{abstract}

Keywords: Heat Stress, Wheat, Canopy Temperature, Dry Matter Translocation, Rht8

\section{Introduction}

High temperature stress is a major environmental constraint limiting wheat productivity in many parts of the world. The optimum temperature for all physiochemical processes of wheat from vegetative to reproductive stage is $20^{\circ} \mathrm{C}$ or lower [1]. The bread wheat, which originated in Mediterranean region, migrated to the cooler climate of temperate regions. It also migrated to warmer regions and conquered the subtropical areas particularly after development of suitable semi-dwarf varieties. Wheat cultivation continue to spread in non-traditional areas. Further spread in subtropical/tropical areas will depend upon ability of this crop to tolerate warm climate. The global warming is likely to change the climate of conventional wheat growing areas and the wheat varieties should have tolerance to higher temperature.

India is the second largest producer of wheat. In India, spring wheat is cultivated, which is sown at the beginning of winter and harvested in the beginning of summer. The total area under wheat cultivation is divided in to six agro-climatic zones. Wheat crop experiences high temperature stress throughout crop season in warmer areas (Central and Peninsular zones) and at or after anthesis in North Western Plains Zone (NWPZ) and North Eastern Plains Zone (NEPZ). Heat stress damages the plant system in a complex manner by disrupting cell membranes [2], enzyme deactivation, and disruption of metabolic pathways. This damage affects photosynthetic activity, accelerate leaf senescence [3] and also affects quality by lowering the glutenin to gliadin ratio [4]. Genetic basis of thermotolerance has been established and genes have been localised on chromosomes 3A, 3B, 4A, $4 \mathrm{~B}$ and $6 \mathrm{~A}[5]$. 
Table 1. MTS and TTC values (\%) and their correlation with yield and biomass.

\begin{tabular}{lll}
\hline Parameter & MTS values & TTC values \\
\hline Range & $21.7-73.2 \%$ & $14.1-61.3 \%$ \\
Mean & 46.4 & 38.0 \\
C.V. (\%) & 11.6 & 16.3 \\
Correlation with grain yield per plant & $0.366^{\mathrm{ns}}$ & $0.760^{*}$ \\
Correlation with grain yield per metre & $0.232^{\mathrm{ns}}$ & $0.756^{*}$ \\
Correlation with biomass per plant & $0.430^{\mathrm{ns}}$ & $0.762^{*}$ \\
Correlation with biomass per metre & $0.346^{\mathrm{ns}}$ & $0.758^{*}$ \\
\hline
\end{tabular}

$* *$ significance at $1 \%$ level

*significance at $5 \%$ level

Genetic improvement of wheat crop for thermotolerance would require evaluation of cultivated wheat germplasm for heat tolerance. Indian wheat cultivars are developed to suit the requirements of different agro climatic zones and represent wide variability in terms of form and characteristics. However, this variability has been largely exploited for improving yields in favourable environments and for biotic stresses particularly foliar diseases. The stability of wheat grain production and further improvements in the yield potential will depend upon ability of the crop to withstand high temperature stress and fluctuations in the temperatures. There is a need to thoroughly assess these germplasm for heat tolerance and to mine the genes governing high temperature tolerance. In this paper, the studies conducted to evaluate wheat germplasm for high temperature tolerance and techniques used are discussed.

\section{Physiological Studies to Understand Thermotolerance}

Estimation of membrane thermostability and cell viability after heat stress treatment of hardened seedlings have been widely used for assessment of high temperature tolerance [611].Cell membrane stability assay measures electrolyte leakage after heat stress treatment to leaf discs of hardened plants [12-15]. The triphenyl tetrazolium chloride (TTC) reduction assay measures the level of mitochondrial respiration activity [16], which serves as an indicator of cell viability. Fifty-six Indian bread wheat genotypes were assayed for acquired thermotolerance at seedling stage. Ten days old seedlings were hardened and then subjected to membrane thermo stability (MTS) and cell viability (TTC reduction) assays. Variability was detected among the 56 genotypes for acquired thermotolerance. The MTS values ranged from 21.7 to $73.2 \%$ and TTC values ranged from 14.1 to $61.3 \%$ (Table1). Significant correlation was observed between MTS and TTC values. TTC assay showed positive correlation with grain yield under high temperature stress and it could be used as a selection criterion in breeding for warmer areas.

The tolerant genotypes identified in this study were used as parents for developing high yielding and thermotolerant selections. In segregating generations of a cross of HD2281 and NIAW34, the selection was done on grain yield per plant and grain yield per plot basis. A set of 15 selections obtained in $F_{4}$ generation were further advanced to $F_{8}$ generation by single plant selections made in subsequent generations. These $\mathrm{F}_{8}$ generation selections showed higher thousand kernel weight (TKW) than parent HD2281, NIAW34 and checks used in trials at two locations, Trombay and Pune for three years. The thousand kernel weight $(\mathrm{g})$ data for the year 201011 was presented in Table 2 .

Table 2. Thousand Kernel Weight (g) of selections at two different locations (2010-11).

\begin{tabular}{|c|c|c|}
\hline Selection /Genotype & $\begin{array}{l}\text { Thousand Kernel } \\
\text { Weight (g) at Trombay }\end{array}$ & $\begin{array}{l}\text { Thousand Kernel } \\
\text { Weight (g) at Pune }\end{array}$ \\
\hline HD2281 (Parent1) & $37.3 \pm 0.7$ & $46.0 \pm 0.9$ \\
\hline NIAW34 (Parent2) & $25.7 \pm 0.4$ & $39.2 \pm 1.0$ \\
\hline Selection 1 & $41.0 \pm 0.7$ & $47.7 \pm 1.5$ \\
\hline Selection2 & $42.9 \pm 0.7$ & $47.5 \pm 0.4$ \\
\hline Selection 3 & $39.3 \pm 0.3$ & $47.9 \pm 0.9$ \\
\hline Selection4 & $40.6 \pm 0.6$ & $48.0 \pm 1.4$ \\
\hline Selection 5 & $38.4 \pm 0.8$ & $47.4 \pm 0.9$ \\
\hline Selection6 & $37.8 \pm 0.4$ & $47.0 \pm 0.5$ \\
\hline Selection 7 & $38.7 \pm 0.4$ & $46.8 \pm 0.4$ \\
\hline Selection8 & $40.3 \pm 0.1$ & $50.1 \pm 1.6$ \\
\hline Selection 9 & $41.3 \pm 0.1$ & $48.9 \pm 0.7$ \\
\hline Selection 10 & $38.0 \pm 0.3$ & $48.0 \pm 0.2$ \\
\hline Selection 11 & $41.3 \pm 0.6$ & $48.2 \pm 0.5$ \\
\hline Selection 12 & $39.3 \pm 0.06$ & $48.2 \pm 1.1$ \\
\hline Selection 13 & $37.0 \pm 0.2$ & $45.3 \pm 0.6$ \\
\hline MACS6222 (Check1) & $26.3 \pm 0.5$ & $41.2 \pm 1.3$ \\
\hline RAJ4083 (Check2) & $23.9 \pm 0.2$ & $36.6 \pm 1.2$ \\
\hline MACS3125 (Check3) & $26.9 \pm 0.9$ & $49.3 \pm 0.8$ \\
\hline Mean & 36.8 & 46.6 \\
\hline LSD $(5 \%)$ & 1.49 & 2.78 \\
\hline
\end{tabular}

\section{Canopy Temperature Depression Studies}

In this study, our hypothesis is that plant architecture can affect canopy temperature. Temperature differences between any two plant canopies with different morphological traits (plant color, waxiness, leaf size, spike size, and awns) may result from a difference in energy absorption. Canopy temperature depression (CTD), the difference between air temperature and canopy temperature as criteria to avoid evapotranspiration under heat stress is one of the parameter to measure tolerance [17]. An experiment was carried out at Gamma field, Bhabha Atomic Research Centre, Trombay to measure CTDs in 15 varieties, which include heat tolerant and sensitive genotypes with difference in tolerance level at different stages. The CTDs was measured with Infrared thermometer (IRT). CTDs were measured at different crop 
growth stages from tillering to flag leaf senescence at weekly interval. Measurements were taken during midday when the temperature was reaching to a maximum in a day in a replicated manner. The genotypes showed difference for CTD at different stages. The data for all agronomic traits on five plants of each variety was recorded. The results showed that significant differences were present among varieties for CTD measured at tillering, boot stage, anthesis and grain filling (Table 3). The canopy temperature differences decreased as plant undergoes maturity. The average CTD values for all genotypes were maximum at tillering stage $\left(7.24^{\circ} \mathrm{C}\right)$ followed by boot $\left(6.12^{\circ} \mathrm{C}\right)$, anthesis $\left(5.30^{\circ} \mathrm{C}\right)$ and grain filling stage $\left(4.42^{\circ} \mathrm{C}\right)$, respectively. Further, correlation analysis showed association of canopy temperature depression at tillering and anthesis stage with grain yield per plant, grain yield per square metre and biomass per square metre. However, the canopy temperature depression at boot stage and grain filling nave not shown any association with grain yield but CTDs at boot stage showed association with biomass per square metre (Table 4). In this study, positive association of CTD at tillering stage with grain yield implied that CTD can be used as selection criteria and can be measured at early stages (tillering) in the breeding programs.
Table 3. Canopy Temperature Depression (CTD) values at different grwoth stages.

\begin{tabular}{lllll}
\hline Genotype & $\begin{array}{l}\text { Tillering } \\
\left({ }^{\circ} \mathbf{C}\right)\end{array}$ & $\begin{array}{l}\text { Boot } \\
\text { stage }\left({ }^{\circ} \mathbf{C}\right)\end{array}$ & $\begin{array}{l}\text { Anthesis } \\
\left({ }^{\circ} \mathbf{C}\right)\end{array}$ & $\begin{array}{l}\text { Grain } \\
\text { filling }\left({ }^{\circ} \mathbf{C}\right)\end{array}$ \\
\hline C306 & 7.30 & 7.18 & 5.20 & 5.10 \\
PBW373 & 9.25 & 8.00 & 5.32 & 4.88 \\
HD2687 & 8.30 & 6.25 & 5.25 & 4.75 \\
RAJ3777 & 5.20 & 4.80 & 4.15 & 4.00 \\
RAJ4037 & 5.24 & 4.63 & 3.95 & 3.60 \\
RAJ4083 & 5.48 & 5.15 & 4.05 & 3.90 \\
PBW435 & 7.50 & 5.63 & 6.20 & 3.75 \\
Kalyansona & 6.08 & 5.65 & 3.60 & 3.50 \\
HD2281 & 8.42 & 8.00 & 7.10 & 5.40 \\
Ajantha & 7.80 & 5.52 & 5.20 & 3.20 \\
HD2189 & 8.00 & 6.20 & 5.80 & 3.75 \\
NIAW34 & 5.10 & 4.21 & 3.60 & 3.55 \\
NIAW917 & 7.30 & 7.20 & 6.12 & 3.60 \\
MP3054 & 9.80 & 8.00 & 7.30 & 7.10 \\
HW2003 & 7.90 & 7.65 & 6.80 & 6.15 \\
Mean & 7.24 & 6.12 & 5.30 & 4.42 \\
LSD $(5 \%)$ & 0.35 & 0.81 & 0.35 & 0.40 \\
\hline
\end{tabular}

Table 4. Correlation coefficients of CTD at different stages with all the plant traits.

\begin{tabular}{lllllllll}
\hline $\begin{array}{l}\text { Trait } \\
\text { CTD }\end{array}$ & $\begin{array}{l}\text { Plant height } \\
\text { (cm) }\end{array}$ & $\begin{array}{l}\text { Days to } \\
\text { maturity }\end{array}$ & Days to anthesis & $\begin{array}{l}\text { Grain } \\
\text { number }\end{array}$ & $\begin{array}{l}\text { Grain } \\
\text { yield/spike }\end{array}$ & $\begin{array}{l}\text { Grain } \\
\text { yield /plant }\end{array}$ & $\begin{array}{l}\text { Grain yield } \\
\text { /sq. mt }\end{array}$ & Biomass/sq.mt \\
\hline CTD (Tillering) & $0.55^{*}$ & $0.59^{*}$ & $0.66^{*}$ & 0.33 & $0.73^{* *}$ & $0.77^{* *}$ & $0.64^{*}$ & $0.66^{* *}$ \\
CTD (Boot stage) & $0.63^{* *}$ & $0.82^{* *}$ & $0.77^{* *}$ & 0.25 & 0.36 & 0.36 & 0.18 & $0.57^{*}$ \\
CTD (Anthesis) & $0.53^{*}$ & 0.42 & 0.38 & -0.04 & 0.55 & $0.72^{* *}$ & $0.67^{*}$ & $0.83^{* *}$ \\
CTD (grain filling) & 0.25 & $0.60^{*}$ & 0.46 & 0.16 & 0.27 & 0.46 & 0.25 & 0.48 \\
\hline
\end{tabular}

$* *$ significance at $1 \%$ level

*significance at $5 \%$ level

\section{Translocation of Dry Matter in 1B-1R and Non 1B-1R Genotypes Studies}

High temperature stress accelerates the plant development and resulted in overall reduction in plant size [18]. A number of studies established an increase in respiration [19], reduction in photosynthesis [20], inhibition of starch synthesis in kernels [21], reduction in kernel number and weight [22] and overall acceleration of senescence as a result of heat stress. The final effect of all these physiological changes is reduction of yield under heat stress. One of the trait most affected is synthesis of pre anthesis and post anthesis assimilates in plant and further their translocation during grain filling. Studies in our lab from past few years showed lower thousand kernel weight in genotypes carrying $1 \mathrm{~B}-1 \mathrm{R}$ translocation as compared non $1 \mathrm{~B}-1 \mathrm{R}$ carrier genotypes under warmer climate. To find the evidence for lower thousand-kernel weight, an experiment is planned to measure the pre anthesis and post anthesis dry mater production and its translocation under high temperature conditions in 1B-1R genotypes and non 1B-1R genotypes. An experiment was carried to study role of $1 \mathrm{~B}-1 \mathrm{R}$ translocation on grain development and final grain size under heat stress. Eight varieties, of which four carried 1B-1R and four without $1 \mathrm{~B}-1 \mathrm{R}$ translocation, were grown in winter, 2010-2011. Each variety was replicated five times in the experiment. Two tallest tillers of each variety from each replication were cut from base and collected from ear emergence to grain harvest at 10-day interval. These tillers were air and then oven dried $\left(60^{\circ} \mathrm{C}\right)$. Each tiller was dissected to separate chaff, grains, leaves and stem. The chaff, grain, leaves and stem were collected and put into separate packets and their weights were taken. The weights of these plant parts were used to estimate translocation of stem reserve to developing grains at each stage. 
Table 5. Translocation of dry matter (TDM), contribution of pre-anthesis assimilates to grain (CPA) and translocation efficiency (TE) in bread wheat genotypes with $1 B-1 R$ translocation and non $1 B-1 R$ translocation.

\begin{tabular}{|c|c|c|c|c|c|c|c|c|}
\hline Genotypes & $\begin{array}{l}\text { Total above gro } \\
\text { produced (mg) }\end{array}$ & nd dry matter & & & & & & \\
\hline 1B-1R genotypes & Anthesis (mg) & Maturity (mg) & $\begin{array}{l}\text { Grain yield } \\
\text { (mg/plant) }\end{array}$ & Grains/spike & $\begin{array}{l}\text { TDM } \\
(\mathrm{mg})\end{array}$ & $\begin{array}{l}\mathrm{TE} \\
(\%)\end{array}$ & $\begin{array}{l}1000 \text { grain } \\
\text { weight (g) }\end{array}$ & $\begin{array}{l}\text { CPA } \\
(\%)\end{array}$ \\
\hline WH542 & 2216 & 1674 & 1191 & 50.7 & 542 & 25.7 & 24.4 & 45.5 \\
\hline HD2687 & 2717 & 2062 & 1462 & 62.3 & 655 & 27.3 & 24.1 & 44.8 \\
\hline HUW206 & 3378 & 2868 & 1851 & 65.0 & 510 & 32.5 & 15.1 & 27.5 \\
\hline PBW343 & 2643 & 2018 & 1321 & 46.0 & 625 & 27.4 & 23.6 & 47.3 \\
\hline Mean & 2738.5 & 2155.5 & 1456 & 56.0 & 553 & 28.2 & 21.8 & 41.3 \\
\hline LSD (5\%) & 686.5 & 485.6 & 212.0 & 18.0 & & 3.10 & & \\
\hline $\begin{array}{l}\text { Non 1B-1R } \\
\text { genotypes }\end{array}$ & $\begin{array}{l}\text { Anthesis } \\
(\mathrm{mg})\end{array}$ & $\begin{array}{l}\text { Maturity } \\
(\mathrm{mg})\end{array}$ & $\begin{array}{l}\text { Grain yield } \\
\text { (mg/plant) }\end{array}$ & Grains/spike & $\begin{array}{l}\text { TDM } \\
(\mathrm{mg})\end{array}$ & $\begin{array}{l}\mathrm{TE} \\
(\%)\end{array}$ & $\begin{array}{l}1000 \text { grain weight } \\
\text { (g) }\end{array}$ & $\begin{array}{l}\text { CPA } \\
(\%)\end{array}$ \\
\hline Ajantha & 3354 & 2297 & 1644 & 36.0 & 1057 & 31.5 & 40.7 & 64.3 \\
\hline HD2189 & 2966 & 2175 & 1657 & 38.0 & 791 & 26.6 & 36.4 & 47.7 \\
\hline PBW435 & 2360 & 1699 & 1812 & 44.3 & 661 & 28.0 & 43.8 & 36.5 \\
\hline Sonalika & 1875 & 1204 & 1360 & 32.0 & 671 & 35.8 & 42.3 & 49.3 \\
\hline Mean & 2638.75 & 1843.75 & 1618 & 37.6 & 795 & & 40.8 & \\
\hline LSD (5\%) & 590.5 & 432.0 & 224 & 9.0 & & & 4.12 & \\
\hline
\end{tabular}

The data showed more accumulation of pre anthesis assimilates $2738.5 \mathrm{mg}$ in $1 \mathrm{~B}-1 \mathrm{R}$ genotypes and the lesser accumulation in non 1B-1R genotypes of about $2638.75 \mathrm{mg}$. However, the total matter translocated during grain filling is more in non $1 \mathrm{~B}-1 \mathrm{R}$ genotypes as compared to $1 \mathrm{~B}-1 \mathrm{R}$ genotypes. The genotypes Ajantha, HD2189, PBW435 and Sonalika had mean translocated matter of $795 \mathrm{mg}$ as compared to $553 \mathrm{mg}$ of 1B-1R genotypes during grain filling period (Table 5). Translocation efficiency and contribution of plant assimilates is higher in non 1B-1R genotypes as compared to 1B-1R genotypes. Consequently, the grain yield per plant and 1000-kernel weight is higher in non 1B-1R genotypes as compared to $1 \mathrm{~B}-1 \mathrm{R}$ genotypes. The results of study showed that the genotypes with $1 \mathrm{~B}-1 \mathrm{R}$ translocation were found to be poor in mobilization of dry matter under warmer climate.

\section{Rht8 Gene Studies in Bread Wheat under Heat Stress}

Productivity potential of bread wheat (T. aestivum L.) is not fully realized because of biotic and abiotic stresses, which the plant faces in field. In recent times, heat stress has emerged as a major problem in the sub-tropical wheat cultivation areas due to climate change. Therefore, agronomically desirable plant type with tolerance to heat stress has become a necessity. Earlier, significant improvement in yield was made with reduction in plant height associated with reduced lodging and improved partitioning efficiency. The $\mathrm{GA}_{3}$ insensitive dwarfing genes (RhtBlb and RhtD1b) have contributed significantly to yield improvement in India [22-24] and worldwide [25-27].
However, the varieties carrying 'Norin 10' genes are sensitive to heat stress and show reduced fertility and yield under high temperatures as observed in Southern European environments [28, 29]. Short stature varieties grown in Southern European countries are responsive to $\mathrm{GA}_{3}$ and carry a different semi-dwarfing gene, which reduces plant height by $10 \%$ without significant reduction in yield [30-32]. The microsatellite locus Xgwm261 shows polymorphism with predominance of 164bp, 174bp and 192bp alleles. The 192bp allele in wheat varieties from Germany, UK and Yugoslavia showed that it reduces plant height by 10 and $8 \mathrm{~cm}$ as compared to 164 and 174bp alleles respectively [33-35]. The semi-dwarfing effect of the 192bp allele is due to a tight linkage $(0.6 \mathrm{cM})$ with the gene Rht8. The $192 \mathrm{bp}$ allele has been used as a marker for Rht8 to study its distribution worldwide and to demonstrate its effect on agronomic traits [36-40]. Screening of allelic variation at XGWM261 microsatellite locus showed that considerable variation is present at this locus however, the gene Rht 8 found to be absent. It was found that $192 \mathrm{bp}$ allele present in Indian genotypes was a height neutral allele as the genotypes possessing 192bp allele did not show height reduction and yield superiority in two environments [41]. A crossing programme was started to transfer $192 \mathrm{bp}$ linked Rht8 gene from donor Chuan Mai 18 to Ajantha (165bp carrier at Xgwm261 locus) and MP3054 (174bp at Xgwm261 locus) to analyse the effect of Rht8 gene. In F6 generation, the segregants carry Rht8-192bp allele, 165bp or $174 \mathrm{bp}$ alleles were grouped, and the mean values for plant height and grain yield were calculated to study the effect of $R h t 8$ gene on plant height and grain yield. The results showed reduction in mean culm height and plant height $(\mathrm{cm})$ in segregants of cross (Chuan Mai 18 with MP3054) over the tall parent, 
MP3054 (Table 6). The segregants showed reduced spike length however, spikelet density found to be improved.

Table 6. Effect of 192bp-Rht8 gene on plant height and other yield components.

\begin{tabular}{llllll}
\hline Genotype at Xgwm261 locus & Culm length (cm) & Plant height $(\mathrm{cm})$ & Spike length $(\mathrm{cm})$ & Spikelet number & Spikelet denesity \\
\hline 192bp-Rht8 gene & $50.0 \pm 1.19$ & $58.5 \pm 1.29$ & $8.45 \pm 0.21$ & $20.0 \pm 0.40$ & $2.37 \pm 0.07$ \\
174bp & $54.4 \pm 0.92$ & $64.5 \pm 1.00$ & $10.0 \pm 0.28$ & $20.5 \pm 0.39$ & $2.07 \pm 0.05$ \\
ChuanMai18 & $40.9 \pm 0.79$ & $48.6 \pm 0.94$ & $7.70 \pm 0.15$ & $20.6 \pm 0.33$ & $2.70 \pm 0.04$ \\
MP3054 & $65.0 \pm 0.18$ & $76.4 \pm 0.88$ & $11.4 \pm 0.81$ & $20.8 \pm 0.44$ & $2.19 \pm 0.04$ \\
\hline
\end{tabular}

\section{Conclusions}

Heat stress is a complex trait. A thermotolerant genotype needs adaptation for all physiological traits at all plant developmental stages. However, data from seedling assays experiment showed that the seedling thermotolerance was correlated with adult plant performance. Canopy temperature depression (CTD), which is an integrative measure of plant's ability to counteract stress, showed that CTD measured at tillering and anthesis stage associated with grain yield and biomass in field studies. Introduction of milder reduced height gene Rht8 showed that balanced plant architecture is the key to achieve final grain yield improvement particularly in taller genotypes. The studies implied that the breeding programme aimed to develop intrinsically thermotolerant genotypes should involve strategies to combine gene combinations for various plant physiological processes and selection should be based on final plant yield under heat stress.

\section{References}

[1] Al-Khatib K and Paulsen GM. Enhancement of thermal injury to photosynthesis in wheat plants and thylakoids by high light intensity. Plant Physiol.1989; 190:1041-1048.

[2] Al-Khatib K and Paulsen GM. High temperature effects on photosynthetic processes in temperate and tropical cereals. Crop Sci.1999;39: 119-125.

[3] Harding SA, Guikema JA and Paulsen GM. Photosynthetic decline from high temperature during maturation of wheat: I. Interaction with senescence processes. Plant Physiol.1990;92:648-653

[4] Blumenthal C, Bekes F, Gras PW, Barlow FW and Rand Brigley $\mathrm{CW}$. Identification of wheat genotypes tolerant to the effects of heat stress on grain quality. Cereal chemistry. 1995;7:539-544

[5] Sun QX and Quick JS. Chromosomal locations of genes for heat tolerance in tetraploid wheat. Cereal Res. Com. 1991;19:431-437

[6] Chen HH, Shen ZY and Li PH. Adaptability of crops to high temperature stress. Crop Sci. 1982; 22:719-725.

[7] Krishnan M, Nguyen HT and Burke JJ. Heat shock protein synthesis and thermal tolerance in wheat. Plant Physiol.1989; 90:140-145.

[8] Vierling RA \& Nguyen HT. Heat shock protein gene expression in diploid wheat genotypes differing in thermal tolerance. Crop Sci. 1992; 32:370-377.

[9] Blum A. Plant breeding for stress environments. CRC Press, Boca Raton, 1988, 201.

[10] Ibrahim AMH and Quick JS. Heritability of heat tolerance in winter and spring wheat. Crop Sci. 2001a; 41:1401-1405.

[11] Ibrahim AMH and Quick JS. Genetic control of high temperature tolerance in wheat as measured by membrane thermostability. Crop Sci. 2001b; 41:1405-1407.

[12] Sullivan CY. Mechanisms of heat and drought resistance in grain sorghum and methods of measurement. Sorghum in seventies, NGP Rao and LR House, Oxford and IBH publishing, New Delhi, India. 1972.

[13] Martineau JR, Specht JE, Williams JH and Sullivan CY. Temperature tolerance in soybeans. 1. Evaluation of a technique for assessing cellular membrane thermostability. Crop Sci. 1979; 19:75-78.

[14] Blum A and Ebercon A. Cell membrane stability as a measure of drought and heat tolerance in wheat. Crop Sci.1981; 21:4347.

[15] Saadalla MM, JF Shanahan and JS Quick. Heat tolerance in winter wheat: I. Hardening and genetic effects on membrane thermostability. Crop Sci.1990a;30: 1248-1251.

[16] Towill LE and Mazur P. Studies on the reduction of 2, 3, 5triphenyl tetrazolium chloride as a viability assay for plant tissue culture. Can. J. Bot. 1974; 53: 1097-1102.

[17] Shipler L and Blum AB. Heat tolerance for yield and its components in different wheat cultivars. Euphytica.1991; $51: 257-263$.

[18] Berry $\mathrm{J}$ and Bjorkman O. Photosynthetic response and adaptation to temperature in higher plants. Ann. Rev. Plant. Physiol. 1980; 31:491-532.

[19] Al-Khatib K \& Paulsen GM. Mode of high temperature injury to wheat during grain development. Plant Physiol. 1984; 61:363-368.

[20] Jenner CF. Effects of exposure of wheat ears to high temperature on dry matter accumulation and carbohydrate metabolism in the grain of two cultivars. I. Immediate responses. Aust. J. Plant Physiol. 1991; 18:165-177.

[21] Warrington IJ, Dunstone RL and Green LM. Temperature effects at three developmental stages on yield of wheat ear. Aust. J. Agric. Res. 1977; 28:11-27.

[22] Sourdille P, Charmet G, Trottet M, Taxies M H, Boeuf C, Negre S, Barloy D and Bernard M. Linkage between RFLP molecular markers and the dwarfing genes $R h t B 1 b$ and RhtDlb in wheat. Hereditas. 1998; 128:41-46. 
[23] Hedden P. The genes of Green Revolution. Trends in Genetics. $2003 ; 19: 1$.

[24] Gale MD and Youssefian S. Dwarfing genes in wheat, GE Russel (ed), Progress in plant breeding vol1, Butterworth, London, 1985; 1-35.

[25] Slafer GA, Satorre EH and Andrade FH. Increases in grain yield in bread wheat from breeding and associated physiological changes. Genetic Improvement of Field Crops (eds) by GA Slafer, Marcel Dekker Ins, New York, 1994:pp.168 .

[26] Calderini DF, Dreccer MF and Slafer GA. Genetic improvement in wheat yield and associated traits. Reexamination of previous results and latest trends. Plant Breed. $1995 ; 114: 108-112$

[27] Worland AJ and Law CN. An effect of temperature on fertility of wheat containing the dwarfing genes Rht1, Rht2 \& Rht3. Annual Report of Plant Breeding Institute, Cambridge.1985:69-71.

[28] Kertesz Z, Flintham JE and Gale MD. Effects of dwarfing genes on wheat grain yield and its components under Eastern European conditions. Cereal Res. Commun.1991;19:297-304.

[29] Worland AJ and Law CN. Genetic analysis of chromosome 2D of wheat. The location of genes accelerating height, day length insensitivity and yellow rust resistance. Z Pflanzenzucht 1986; 96:331-345.

[30] Worland AJ, Law CN and Petrovic S. Pleiotropic affects of the chromosome 2D genes Ppdl, Rht8 and Yr16, In Proceedings of the seventh International Wheat Genetics Symposium, Cambridge, TE Miller and RMD Koebner (ed). 1988a; 669674.

[31] Worland AJ, Law CN and Petrovic S. Genetic analysis of chromosome 2D of wheat. II. The importance of this chromosome to Yugoslavian varieties. Plant Breed. 1988b; 100:247-259.
[32] Worland AJ, Korzun V, Ganal, MW, Roder, MS and Law CN. Genetic analysis of the dwarfing gene Rht 8 in wheat. Part II. The distribution and adaptive significance of allelic variants at Rht 8 locus of wheat as revealed by microsatellite screening. Theor. Appl. Genet. 1998; 96:1110-1120.

[33] Worland AJ, Sayers EJ and Kurzun V, Allelic variation at the dwarfing gene Rht 8 locus and its significance in international breeding programmes. Euphytica. 2001; 119: 155-159.

[34] Ahmad M and Sorrels ME. Distribution of microsatellite alleles linked to Rht8 dwarfing gene in wheat. Euphytica.2002; 123: $235-240$

[35] Bai G, Das MK, Carver BF, Xu X and Krenzer EG. Covariation for microsatellite marker alleles associated with Rht8 and coleoptile length in winter wheat, Crop Sci. 2004; 44:1187-1194.

[36] Rebetzke G J and Richards R. Gibberellic acid-insensitive wheats reduce plant height to increase kernel number and grain yield of wheat. Aust. J. Agric. Res. 2000; 51:251-265.

[37] Ganeva G, Korzun V, Landjeva S, Tsenov N and Atanastova M. Identification, distribution and effects on agronomic traits of the semi dwarfing Rht alleles in Bulgarian common wheat cultivars. Euphytica. 2005;145:305-315.

[38] Liu Y, Liu D, Zhang H, Wang J, Sun J \& Guo X. Allelic variation, sequence determination and microsatellite screening at the Xgwm261 in Chinese hexaploid wheat (Triticum aestivum) varieties. Euphytica. 2005; 145:103-112.

[39] Zhang X, Yang S, Zhou Y, Xia X and He Z. Distribution of the $R h t B 1 b, R h t D 1 b$ and $R h t 8$ reduced height genes in autumn sown Chinese wheats detected by molecular markers. Euphytia. 2007; 152:109-116.

[40] Bakshi S and Bhagwat SG. Allelic variations at Xgwm261 locus, sequence determination and agronomic evaluation in Indian bread wheat genotypes. Cereal Research Communications.2012;40:34-43. 